\title{
KEYNES' ECONOMIC THOUGHT AND THE THEORY OF CONSUMER BEHAVIOUR
}

\author{
S. A. DRAKOPOUlOS* \\ University of Aberdeen
}

\section{INTRODUCTION}

Although there is a large literature on the subject of the microeconomic foundations of Keynes's macroeconomics, it seems that the subject of Keynes' views on the theory of consumer behaviour has been taken for granted. In particular, there is considerable controversy over other aspects of microeconomic foundations (wage theory, monetary theory, investment theory); somehow however, there is almost universal agreement among economists about consumer behaviour theory. Generally, an implicit (or sometimes explicit) idea prevails that the utility maximizing model is perfectly compatible with Keynesian economics, and this naturally implies a belief that Keynes accepted that model. This can be seen in various theoretical discussions like the consumption function, the controversy over Keynes' and Walras' law, the asset choice model and generally in attempts to combine Keynesian macroeconomics with Neoclassical General Equilibrium theory. The work of such theorists as Klein (1949), Patinkin (1965), Clower (1965), Leijonhufvud (1967), Barro and Grossman (1971), Malinvaud (1977) and Hahn (1980), is indicative. (Even Post-Keynesian theorists have not paid the proper attention to this issue.)

The purpose of this paper is to demonstrate that although Keynes was not particularly interested in consumer behaviour, there are strong signs that he actually rejected the standard theory of consumer behaviour and especially the expected utility model. This can also help to explain a number of problems about the microeconomic foundation of his macroeconomic ideas. Furthermore, one can discern ideas in Keynes which might be taken as an outline of an alternative model of consumer choice, and if one is willing to connect these ideas with modern alternative formulations of consumer behaviour, they might be seen as an additional explanation for issues like sticky prices and Keynesian unemployment.

The paper starts with a discussion of the attempt to connect Neoclassical

\footnotetext{
* Special thanks are due to Dr Sheila Dow, Professor P. J. Sloane and to two anonymous referees of this journal. The usual disclaimer applies.
} 
microfoundations with Keynes' economic thought. The next section is concerned with Keynes' rejection of the standard theory as is found in his 'General Theory' but also other writings. A discussion of signs for alternative formulations in the work of Keynes, and possible alternative models which can be connected with these, is the subject matter of the two subsequent sections. Finally, the implications of the above for Keynesian macroeconomics are assessed.

\section{MICROECONOMIC FOUNDATIONS}

Some years after the publication of Keynes' 'General Theory', a number of economists attempted to integrate Keynes' ideas within the standard Neoclassical framework. More specifically, many Neoclassical theorists saw the apparent lack of microfoundations in Keynes as a deficiency in the sense that aggregative analysis had not been connected with the individual economic agent's behaviour (Dow, 1985, p. 89). According to the prevailing methodological Neoclassical framework it was necessary that macroeconomics should have a firm basis on microeconomic principles. These microeconomic principles were basically the marginalist microeconomics, the most important components of which are utility maximizing consumers and profit maximizing firms. These attempts were made easier mainly because of the apparent lack of specific microeconomic principles in Keynes' work. Leaving aside the attempts to incorporate other aspects of the standard microeconomics, we will concentrate on the theory of consumer behaviour.

One of the first attempts were made by Klein in 1949. His purpose was to derive the Keynesian macroeconomics by using the standard microeconomic assumptions. The idea that a 'household maximizes its satisfaction subject to the constraint of its budget' is central in Klein's work (Klein, 1949, p. 58). In the same climate Patinkin, in his 'Money, Prices and Interest' also accepted the idea of the utility maximizing agent (Patinkin, 1965). This can also be seen in more specialized works like that of Tobin's liquidity preference theory where utility maximizing agents are introduced in a Keynesian framework (Tobin, 1958).

Some authors like Clower and Leijohnufvud require more attention since they were the first to explicitly address the issue of the appropriateness of integration between Keynesian macroeconomics and Neoclassical microeconomics (see Dow, 1985, p. 92). Clower for instance in his discussions of microfoundations was never thought to challenge the standard utility maximizing model assumed by other theorists. In particular, although he realizes the possibility of Keynes' rejection of the standard theory, he seems to regard it as somewhat unthinkable (Clower, 1965, pp. 277-78). Clower asserts that Keynes' rejection of the Walras' law does not refer to the one he thought he was attacking, because if it did he would have to reject the theory of household behaviour (Clower, 1965, p. 278). Clower goes on to suggest a conservative interpretation, 
that Keynes actually questioned the specific theory of household behaviour and that he made use of a more general theory (the dual decision hypothesis), which still however, is based on the idea of utility maximization.

The same framework is followed by Leijonhufvud who sees the transition from Walras' world to Keynes' world as simply the rejection of the assumption of tatonnement mechanism (Leijonhufvud, 1967, p. 301). Leijonhufvud emphasizes that all other classical assumptions, including that individual traders maximize utility, remain as before (Leijonhufvud, 1967, pp. 301, 308). Moreover, in his subsequent work, Leijonhufvud sees nothing wrong with Modigliani's and Friedman's attempts to derive Keynes' consumption function with utility maximization as a basis (Leijonhufvud, 1968, pp. 207-212).

More recent work concerning the microfoundations of the Keynesian macroeconomics, or a synthesis of Keynesian macroeconomics with Neoclassical economics, have not seriously questioned the issue (see Weintraub, 1979). The majority of theorists see it as an unchallenged assumption (for a review see Dow, 1985, pp. 89-97). Moreover, one can also mention here some authors who adopt a positive position and explicitly view Keynes' microeconomic thought as belonging to the standard framework. For instance, a number of well-known theorists like Arrow, Meltzer and Patinkin have suggested that Keynesian thought is in the tradition of the theories of General Equilibrium where one fundamental assumption is the maximization of utility or expected utility (see Arrow, 1974, pp. 25-26; Meltzer, 1981; Patinkin, 1976, p. 98). One can also see this in the work of many Neo-Keynesian theorists who explicitly claim that they are operating in a Keynesian framework, but still adopt the utility maximizing agent. More specifically, authors like Barro and Grossman, Malinvaud and Hahn are indeed prepared to defend the validity of the utility maximizing model in a Keynesian framework (see Barro and Grossman, 1971, 1976; Malinvaud, 1977; Hahn, 1980).

The same can be observed in the history of constructing an aggregate consumption function. The most well known works on the subject also start with the implicit assumption that a utility maximizing model is perfectly compatible with Keynes. The works of Modigliani and Brumberg, Ando and Modigliani, and even Friedman are indicative. The important point is that they all see themselves as working in a Keynesian framework (Modigliani and Brumberg, 1955, pp. 388-391; Ando and Modigliani, 1963, p. 73; Friedman, 1957).

Some attention should be given to Duesenberry's work which tried to take into account some other elements of Keynes' work. Namely, he realized that the standard approach to consumption of other 'Post Keynesian' theorists (ie. Hicks) does not include the crucial ideas of learning and habitual behaviour. He also attacks the idea that consumption decisions are based on rational planning. Duesenberry attempts to reconcile this by constructing a consumption function which is characterized by preference interdependence (Duesenberry, 1949, pp. 24-25). It can be argued that although his consumption function depends on the idea of utility maximization, his formulation-as we shall see-is closer to the original views of Keynes. This may also be seen as the reason for Friedman's attack on Duesenberry's formulations (Friedman, 1957). 


\section{Keynes AND THE UTILITY MAXIMIZING MODEL}

As noted above, Keynes was not very interested in explicitly formulating a consumer theory. However, as was shown, subsequent theorists implicitly or explicitly suggested that he accepted the utility maximizing model (a-temporal or intertemporal) and this by itself makes it important to examine if he actually did. The purpose of this section is to demonstrate that in spite of the lack of microeconomic principles in Keynes' work, his rejection of Benthamite hedonism and his ideas on probability and uncertainty clearly imply his distance from the model.

\section{Historical background}

The Neoclassical interpretations of Keynes' microfoundations can be better understood if we take a brief look at the development of the standard theory of consumer behaviour. In particular, the modern standard theory of the rational consumer is related to the marginalist theory of the economic agent which in turn can be traced in the writings of J. Bentham. Bentham's 'calculus of pleasure and pain' was the basis of the marginalist theory of consumer behaviour which can be found in Jevons, Walras, and Edgeworth (see Bentham, 1823, pp. 1-2; Jevons, 1871, p. 1; Walras, 1965, pp. 125-135; Edgeworth, 1881, p. 5; Hutchison, 1956, p. 290; Loasby, 1976; and for a review Drakopoulos, 1990a).

The change from cardinal utility to ordinal utility (which originated with Pareto but was first formulated by Hicks and Allen), had as its aim a scientific consumer theory freed from subjective concepts like 'pleasure' or 'utility'. The core, however, still remained a utility maximizing agent (Pareto, 1971; Hicks and Allen, 1934; Hicks, 1946). The subsequent introduction of Revealed Preference theory by Samuelson which attempted to give consumer theory an even more objective basis, did not break the basic connections with the marginalist formulations (see Samuelson, 1963; but also Georgescu-Roegen, 1966; and Wong, 1978). The main reason for this trend towards more objectivity was the accusation that the theory had been influenced by utilitarian hedonism (see Samuelson, 1963, p. 91). Naturally modern Neoclassical theorists would strongly deny this accusation (see for instance Malinvaud, 1972, p. 16). There are still strong signs though that even the modern axiomatic formulation of consumer theory remains connected with the Benthamite and marginalist thought. The works of Becker and Myerson where the utility function is explicitly connected with Bentham's pleasure function are indicative (Becker, 1976; Myerson, 1981, and also Veblen, 1972; Drakopoulos, 1990a; and for a historical discussion Coats, 1976). Moreover, concerning the expected utility model, one can safely maintain that its basic conceptual and theoretical apparatus are essentially identical to the standard utility maximizing framework (see 
von-Neumann and Morgenstern, 1953, Loomes and Sugden, 1982, p. 428 and 1983, p. 807).

\section{Mooreian good versus Benthamite pleasure}

As a first indication of Keynes' objection to the model described above of Neoclassical microeconomics, one can mention his strong rejections of Bentham's views and his considerable influence from the anti-hedonistic ideas of Moore. In particular, there are a number of places where Keynes explicitly attacks Bentham, the psychology and the philosophy of hedonism and the Benthamite calculus of pleasure and pain in general.

In a very important passage from his 'My Early Beliefs' written in 1939, he considers himself and his circle as 'the first of our generation, perhaps alone amongst our generation, to escape from the Benthamite tradition' (Keynes, Xp. 445). He continues:

It can be no part of this memoir for me to try to explain why it was such a big advantage for us to have escaped from the Benthamite tradition. But I do now regard that as the worm which has been gnawing at the insides of modern civilization and is responsible for its present moral decay (Keynes, X, p. 445).

In addition, Keynes' anti-hedonistic stance can be seen by his discussion of previous economists in his 'Lives of Economists'. In his discussion referring to Jevons and Marshall, he emphasizes Marshall's superiority and he comments on Jevons' 'bright' ideas as follows:

How disappointing are the fruits, now that we have them, of the bright idea of reducing Economics to a mathematical application of the hedonistic calculus of Bentham (Keynes, X, p. 184n).

In the same manner, he criticizes Edgeworth (the other famous promoter of hedonistic calculus) for not having considered 'how far the initial assumptions of the marginal theory stand or fall with the utilitarian ethics and the utilitarian psychology' (Keynes, X, p. 260).

In place of the greatest pleasure offered by the Benthamite calculus, Keynes suggested the pursuit of the Good. This is mainly the result of influence from G. E. Moore who was a well-known non-hedonist philosopher. Moore condemned utilitarian hedonism as having illogical foundations, and Keynes himself describes Moore as opposed to hedonism (see Frankena, 1963, p. 69; Moore, 1966; Keynes, X, p. 442). Indeed Keynes was more attracted to the idealistic aspect of Moore's philosophical thought which sets as the purpose of life not the pursuit of pleasure but of the Good. (For a discussion of Moore's influence on Keynes, see Skidelsky, 1983; Bateman, 1988; Carabelli, 1988.) It has also been maintained that Keynes' unique conception of probability is heavily based on the concept of Mooreian Good (see Carabelli, 1988, p. 31). In addition Keynes' rejection of Benthamite pleasure as the purpose of life can be connected with his sympathies towards idealistic approaches like 
neo-Platonism (see Fitzgibbons, 1988, pp. 5,64; Bateman, 1988, p. 1099; O'Donnell, 1989).

\section{Probability, uncertainty and expected utility}

Keynes's revoluticnary conception of probability and uncertainty is another important point which puts him at odds with the subsequent standard utility theory. According to Keynes probabilities are either numerically indeterminate or undefinable (see Keynes, VIII, pp. 8-9; Lawson, 1988, pp. 42-44). Moreover, he thought that a probability concept based on frequency is 'a wrong philosophical interpretation of probability' (see Keynes, VIII, p. 342). This is in sharp contrast with the standard expected utility approach which views probability as based on frequency and as numerically measurable (ie. Savage, 1962; Radner, 1968). Related to this is his conception of uncertainty. Uncertainty corresponds to a situation of numerically immeasurable probability. Keynes believed that uncertainty cannot be reduced, mainly because a numerical probability distribution is not known (events are not replicable). Keynesian uncertainty is thus radically different from the reducible and calculable uncertainty which is used in the expected utility model (see Dow, 1985, p. 156; Lawson, 1988, pp. 46-52). As Keynes himself asserted:

By 'uncertain' knowledge, let me explain, I do not mean merely to distinguish what is known from what is only probable. The game of roulette is not subject, in this sense, to uncertainty; nor is the prospect of a Victory bond being drawn. Or, again, the expectation of life is only slightly uncertain. The sense in which I am using the term is that in which the prospect of a European war is uncertain, or the price of copper and the rate of interest twenty years hence, or the obsolesce of a new invention, or the position of private wealth owners in the social system in 1970. About these matters there is no scientific basis on which to form any calculable probability whatever. We simply do not know (Keynes, XIV, pp. 113-114).

Moreover, he was anxious to point out that his views on that had been underestimated, which again indicates the great importance that he attached to this matter (see Dow and Dow, 1985, p. 50).

It is noticeable that a number of subsequent economists either downplayed or misinterpreted Keynes' approach to uncertainty. Tobin for instance, in his asset choice model (operating in a Keynesian framework) conceived of uncertainty as calculable (similarly to risk; Tobin, 1958). The same is true for other authors like Stohs who actually holds that Keynes had a calculable probability conception (see Stohs, 1980). However, this argument has been convincingly attacked by Garner and Weisman (see Garner, 1983; Neisman, 1984). Moreover, although there are differences in interpretation, a Keynesian oriented conception of uncertainty has been discussed and elaborated by Shackle, Lawson and Davidson (Shackle,1974; Lawson, 1987; Davidson, 1983; Gerrard, 1991).

With the above in mind one can understand better his serious objections of what is today termed the expected utility maximization approach. A first indi- 
cation of his reservations was given in an article written in 1937 and published in the Quarterly Journal of Economics. Keynes gives a brief summary of the works of Ricardo, Marshall, Edgeworth and Pigou in relation to their theories of long-run equilibrium. Keynes observes that these writers assumed expectations to be given 'in a definite and calculable form', and also that risks were assumed to be 'capable of an exact actuarial computation' (Keynes, XIV, p. 112). Keynes was dissatisfied with this reduction of 'uncertainty to the same calculable status as that of certainty itself; just as in the Benthamite calculus of pains and pleasures' (Keynes, XIV, p. 113-114). His next step is to outline the standard approach to the problem which according to Keynes is based on the Benthamite calculation. Keynes' verdict is quite strong:

I accuse the classical economic theory of being itself one of these pretty polite techniques which tries to deal with the present by abstracting from the fact that we know very little about the future (Keynes, XIV, p. 115).

In the final section of the article, he sums up his main departure points from the traditional theory. He mentions two points: Say's Law and what can be interpreted as the expected utility approach. With respect to the second he comments:

The orthodox theory assumes that we have a knowledge of the future of a kind quite different from that which we actually possess. This false rationalization follows the lines of the Benthamite calculus. The hypothesis of a calculable future leads to a wrong interpretation of the principles of behaviour which the need for action compels us to adopt... (Keynes, XIV, p. 122).

It is clear that these comments indicate that he had a strong feeling against the Benthamite expected utility approach. However, the most explicit statement against the expected utility and against the utility maximizing model in general can be found in his Galton lecture given in 1937 where he launched another attack on the 'extraordinary conception of the Benthamite school' which generated a 'mythical system of probable knowledge' (see Keynes, XIV, p. 124; O'Donnell, 1989, p. 120). He describes the expected utility model based on the Benthamite school in which 'all possible consequences of alternative courses of action were supposed to have attached to them, first a number expressing the probability of their following from the course of action in question; so that multiplying together the numbers attached to all possible consequences of a given action and adding the result, we could discover what to do' (Keynes, $\mathrm{XIV}$, p. 124). Keynes is quite strict in his rejection of this when he declares:

In this way a mythical system of probable knowledge was employed to reduce the future to the same calculable status as the present. No one has ever acted on this theory. But even today I believe that our thought is sometimes influenced by some such pseudo-rationalist notions (Keynes, XIV, p. 124).

Other arguments which support this view can also be seen in the 'General Theory' itself, where Keynes again adopts a polemic attitude towards the 
expected utility approach (and also towards the hedonistic approach). As he emphatically states:

[It is a] characteristic of human nature that a large proportion of our purposive activities depend on spontaneous optimism rather than on mathematical expectation, whether moral or hedonistic or economic (Keynes, GT, p. 161).

It has to be noted here that recently an increasing number of theorists have realized Keynes' serious reservations about standard microeconomics and especially about the expected utility model (see Bateman, 1988; McQueen, 1988; Speight, 1990, p. 66).

The discussion of consumption in the 'General Theory', is another indication of Keynes' rejection of the utility maximizing model. Also, as will be seen, one can discern some evidence of alternative formulations. Starting from the idea that consumption depends on a) objective and b) subjective factors. Keynes states the following subjective factors which he calls motives: Enjoyment, Shortsightedness, Generosity, Miscalculation, Ostentation and Extravagance. The corresponding list for savings behaviour is: Precaution, Foresight, Calculation, Improvement, Independence, Enterprise, Pride and Avarice (Keynes, GT, p. 108). Keynes gives equal weight to these motives, something which is incompatible with the utility maximizing model. In addition some authors have pointed out that the last three motives for savings undermine any utility maximization based formulation of the consumption function (Johnson, 1971, pp. 36-37). (One can argue that a list of similar motives is supplied by Fisher in his discussion of time preference for income, but this does not prevent him from operating in a utility maximizing framework. Two points have to be noted here: a) there is no sign in the analysis of consumption and savings that economic agents maximize utility, and as will be shown, Keynes would not have wanted to reduce all the motives into utility. By contrast, Fisher constantly uses utility maximization and effectively reduces all motives into utility; b) Fisher identifies uncertainty with calculable probability or risk and this fits with the standard model while Keynes had a totally different stance (see Fisher, 1930, pp. 71,89$)$.

Indications of Alternative Formulations in Keynes

The idea of Keynes' rejection of the utility maximizing model leads to the issue of the possibility of an alternative approach. One can argue that either Keynes did not want to have a microeconomic basis in the sense of Neoclassical theory or that he implicitly had in mind a different approach to consumer behaviour. As far as the second view is concerned, there are passages in his 'General Theory' which might be interpreted as a basis for an alternative theory or theories. In particular having in mind some alternative developments in the 
theory of consumer behaviour, we can interpret Keynes' ideas in this light. But let us see first some relevant quotations from the 'General Theory' itself.

In his discussion of the propensity to consume where he states his wellknown psychological law (that as income increases consumption increases but not as much as the increase of income), he supplies the reason behind this statement. In particular, he asserts that in the short run the importance of habits is great. As he states:

For a man's habitual standard of life usually has the first claim on his income, and he is apt to save the difference which discovers itself between his actual income and the expense of his habitual standard; or, if he does adjust his expenditure to changes in his income, he will over short periods do so imperfectly (Keynes, GT, pp. 97).

It is clear that this emphasis on habitual behaviour is another indication of his objections to the utility maximizing model. This attention to habitual behaviour is not isolated to the above quotation but it can also be found in other places (see for instance Keynes, GT, p. 93, 98). One can also establish a connection between Keynes' conception of uncertainty and his emphasis on habits and customs. In particular, it has been argued that individuals cope with the unquantifiable probability and non-reducible uncertainty that is found in Keynes, by relying on habits and customs (see Lawson, 1985). In addition, Keynes' approach to habitual behaviour reveals some parallel points with other economists who have emphasized the importance of conventional behaviour. For instance, one can note the similarity with the approach of Veblen, who also expressed an explicit rejection of utility maximization and of Benthamite calculus generally (see Veblen, 1972). Just like Keynes, Veblen put emphasis on habits and instincts in order to analyse consumption. (His main example of a consumption which is not based on utility calculus is "conspicuous consumption', see Veblen, 1949, pp. 84,85.)

Keynes adds another dimension to his discussion of consumption when he analyses the relation between income and savings. The idea of higher proportion of income saved as real income increases is justified in the following terms:

... it is also obvious that a higher absolute level of income will tend, as a rule, to widen the gap between income and consumption. For the satisfaction of the immediate primary needs of a man and his family is usually stronger motive than the motives towards accumulation, which only acquire effective sway when a margin of comfort has been attained (Keynes, GT, p. 97).

This quotation illustrates Keynes' belief that most men have similar basic or necessary needs which must be satisfied first. Once these basic needs are satisfied and thus a margin of comfort has been achieved, then other needs come into the picture. This is very similar to what has subsequently been called a hierarchical structure of needs. The basic point of the hierarchical approach is the idea that some needs must be satisfied first, or in other words, that not all needs are reducible (expressed in terms of axiomatic theory this implies that there is no continuous preference substitution, Drakopoulos, 1992). The 
hierarchy might be due to the existence of habits or customs, physiological factors or even to psychological reasons (Earl, 1983). Keynes's emphasis on habits can also be seen in connection to hierarchical needs because the existence of habits makes continuous preference substitution quite difficult.

It can be argued that the hierarchical approach has a different conceptual basis than the standard utility maximizing theory. In particular, it can be associated with psychological theories like Maslow's that imply different agent motivation, and which lie far from the Benthamite tradition (Maslow, 1954; Drakopoulos, 1991). This is also in line with Keynes' distrust of Benthamite philosophy which was observed previously.

If one is willing to make a connection with developments in consumer theory one might connect Keynes' views on need hierarchy with subsequent models of consumer behaviour which attempt to take into account the hierarchical structure of needs. A representative example of such a model is that of Georgescu-Roegen in which there are primary and secondary criteria (Georgescu-Roegen, 1966). We shall see this model in more detail in a subsequent section.

Another indication that Keynes would have favoured an approach which is not based on calculative behaviour is the idea of 'animal spirits' which is used in the discussion of investment. Although Keynes was also willing to accept the influence of maximizing behaviour in the Neoclassical sense (see ch. 11 of 'General Theory' and the concept of 'certainty equivalents'), it is clear that he placed extreme importance on psychological processes which have nothing to do with 'economic calculus' (see Dow, 1989; Carabelli, 1988). In an indicative statement he argues:

Most, probably, of our decisions to do something positive, the full consequences of which will be drawn out over many days to come, can only be taken as a result of animal spirits-of a spontaneous urge to action rather than inaction, and not as the outcome of a weighted average of quantitative benefits multiplied by quantitative probabilities (Keynes, GT, pp. 161-162).

It can be argued that there is a connection between the concept of animal spirits and Keynes' ideas on probability: in a world of Keynesian immeasurable probability, decisions have to be based on something else other than pure calculations. This important aspect of Keynes' thought however, appears not to have been noticed by many Neo-Keynesian or Neoclassical theorists. However, a few have realized the significance of the arguments as for example has Robinson who states: 'The [Keynesian] revolution lay in the change from the principles of rational choice to the problems of decisions based on guesswork and convention'. (In Dow and Dow, 1985, p. 54.) It has to be noted, however, that although Keynes paid more attention to decisions based on non-calculative behaviour, he was not interested to provide a concrete alternative to the standard theory. Still, however, there are some indications which might be interpreted as the basis for an alternative approach.

Before we proceed to a discussion of a possible consumer behaviour theory that is compatible with Keynes' writings, we must make a distinction between 
the utility maximizing model and the other models of behaviour. In the final analysis, the essence of the utility maximizing model is that the subject is assumed to choose between the probability weighted utilities of different outcomes (see also Steinbrunner, 1974). Or in the words of some psychologists subjects are maximally happy across the $n$ activities (Prelec, 1982, p. 222). This can be contrasted with other models where the subject does not engage in alternative outcome calculations. The behaviour of the agent in these cases can be described in many ways: matching (equally happy in each of the $n$ activities); habitual (following specific patterns); or hierarchical (ranking of activities).

\section{V}

\section{Possible Alternative Models}

Now if one is willing to connect Keynes' ideas with some subsequent developments in consumer theory, then a number of alternatives appear. First, an extension of Keynes' comments about the hierarchical structure and customs can lead to a model of consumer behaviour similar to the one described by theorists like Georgescu-Roegen (1966), Little (1957) and Encarnacion (1964). More specifically, in this model there are a number of criteria of choice and these criteria are structured. For example, if there is a choice of food (survival goods) and perfume (luxury goods), the individual prefers food first and after his hunger has been satisfied (threshold) then the other needs come into the picture. (It is obvious that the model is more relevant in relation to bundles of goods rather than to single goods.) In the simple case of two goods, two criteria, the preference ordering can be described as follows:

If $x_{1}$ is food and $x_{2}$ is perfume and $S$ is the survival point beyond which the other needs become relevant, we have:

$$
x^{\prime}=\left(x_{1}^{\prime}, x_{2}^{\prime}\right) \text { and } x^{\prime \prime}=\left(x_{1}^{\prime \prime}, x_{2}^{\prime \prime}\right) \text { and } x^{\prime} P x^{\prime \prime} \text { iff }
$$

either

$$
x_{1}^{\prime \prime}<x_{1}^{\prime}<S,
$$

or

$$
x_{1}^{\prime \prime}=x_{1}^{\prime} \leqslant S ; x_{2}^{\prime \prime}<x_{2}^{\prime},
$$

or

$$
x_{1}^{\prime \prime}<S<x_{1}^{\prime},
$$

or

$$
S<x_{1}^{\prime}, x_{1}^{\prime \prime} ; x_{2}^{\prime \prime}<x_{2}^{\prime} .
$$

This model will not give indifference curves but quasi-indifference curves or behaviour lines (see Georgescu-Roegen, 1966; Little, 1957). The idea of hierarchical structure has also a basis in psychology where a number of 
theorists support it (for a review, see Drakopoulos, 1990b). It must also be emphasized that it is less related to Benthamite hedonism than the standard utility maximizing model. This is because of the idea of irreducible wants which is alien to Benthamite thought. (In Bentham as in many Neoclassical theorists utility is the common denominator of everything, there is no hierarchical structure, see Borch, 1968, Earl, 1983).

Now if one wishes to derive a demand curve from the previously described choice model, the resulting demand curves will be different from the ones which are usually derived from the standard theory. More specifically, the demand curves will have a kink at the point where the need for food (survival) is achieved. Taking the case that the budget constraint is less than the expenditure of food (or necessary goods) $y \leqslant p x_{1}$, the demand curve for good $x_{1}$ will be a rectangular hyperbola up to the point $x^{*}$ (represented by $S$ in the preference description). After this point, the individual starts spending his income on $x_{2}$ As the price falls the consumer continues buying $x_{1}$ but part of his income now is spent on $x_{2}$. A diagrammatic representation of the demand curve will be as follows:

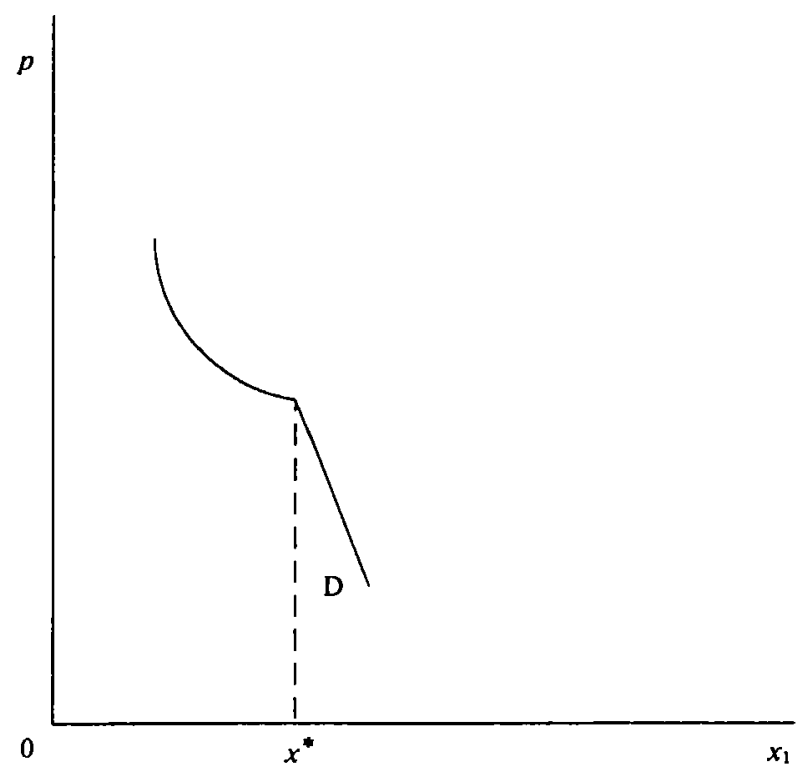

Figure 1.

In a more general model of that type, one might interpret the character of the passage from one criteria to the other as threshold levels. The kink coincides with the threshold or when the next need becomes important. The change in the slope of the demand curve reflects the change in relative efficacy of the good to satisfy subsequent needs. (For a discussion of the general hierarchical model and the resulting demand curves see Drakopoulos, 1992.) 
For illustrative purposes, one might apply the hierarchical model to a conventional consumption-savings framework. If we have a hierarchical utility function for an individual (for a discussion of the nature of hierarchical utility see Fishburn, 1974):

$$
U=U\left(C_{N}, C_{L}, S\right)
$$

where

$C_{N}$ : consumption of necessary goods or threshold consumption,

$C_{L}$ : consumption of luxury goods, $S$ : savings

If we accept that: $C_{N}$ is the first priority, $S$ is the second (because of risk aversion or other psychological reasons), income is higher than the $C_{N}$ expenditure, and that there is no borrowing, then we get the Keynesian result that MPC $<1$. In an aggregate framework the additional assumption that the expenditure for $C_{N}$ is less than average income has to be made.

Again we can see that MPC will be lower than 1 for some individuals and equal to 1 for others (especially for the poor). Overall, the MPC of the aggregate consumption function will be less than unity (If there is an increase in aggregate income then the value of MPC will depend on the distribution of income. The MPC will be higher if the poor people get all the increase). The previous points are in agreement with Keynes' views on consumption, savings and distribution (Keynes, GT, pp. 90-91, 95, 97, 107-109).

\section{SIGNIFICANCE FOR KEYNESIAN MACROECONOMICS}

It is known that a number of explanations have been proposed for Keynes' argument against the continuous market clearing of the Walrasian style. As far as the labour market is concerned, money illusion, implicit contracts, union wages etc., have been suggested. The product market side seems to have received less attention but nevertheless, a number of explanations have been put forward like the cost structure, customer loyalty and others (Gordon, 1990). As an additional explanation of the above one can suggest the alternative consumer theory that we discussed. As we shall see it gives results which are in agreement with Keynes' ideas especially in the product market. (It can be used as a basis for wage inertia too.)

It is a characteristic of the Keynesian system that one of the most important reasons for unemployment is wage and price rigidity. The discussion concerning wage rigidity is well-known, but the idea of price rigidity needs more attention. Keynes himself emphasizes this: 'Apart from those prices that are virtually constant in the short period, there are obviously many others, which are for various reasons, more or less sticky' (Keynes in Sawyer, 1989, p. 99).

Although some theorists have accepted this without further discussion, a number of other theorists have pointed out the inadequacy of Keynes' 
explanation on the underlying causes of sluggishness (see for instance Sawyer, 1989). As Akerlof and Yellen emphasized:

Nevertheless, the reasons why prices and wages do not adjust quickly to changes in aggregate demand remains mysterious (Akerlof and Yellen, 1985, p. 825).

In addition some economists have criticized Keynes for not having sound microeconomic foundations particularly in his justification of price inertia (see Stevenson et al., 1988, p. 108). We believe that if one is willing to accept our interpretation of Keynes' views on consumer theory, one can explain the Keynesian idea of the rigidity observed in the product market. More analytically, the main consequence of the adoption of consumer theories like the hierarchical or the threshold model is that they go against the Walrasian idea of price flexibility, and thus they provide an additional basis for the Keynesian argument. A hierarchical approach to consumer behaviour or the threshold model will most probably give a kinked demand curve. Even if one assumes that only part of the population exhibits this kind of behaviour, then still the total demand will be kinked. This is also due to the fact that the impact of the threshold-sensitive conduct or non-rational behaviour (in the neoclassical sense) is found not to cancel out in the aggregate but rather to have first order consequences. In particular Akerlof and Yellen have shown that the existence of even a relatively small number of economic agents with non-rational behavjour, can result in changes to equilibrium (relative to equilibrium with full maximization) that vary proportionately with the shift parameter (Akerlof and Yellen, 1985). This is reinforced by other findings which have suggested that threshold behaviour expands hyperbolically in the aggregate (Devletoglou and Demetriou, 1967, p. 352).

In spite of the above one might still be doubtful and maintain that the market demand curve will be smooth because the threshold levels occur at different prices for different individuals. However, it is quite likely that the threshold levels will be similar for categories of goods (ie. necessary and luxury goods) for large groups of the population with similar incomes (GeorgescuRoegen, 1966; Earl, 1983). This is especially the case when certain categories of goods (eg. food) correspond to categories of needs (eg. the need to eat).

A combination of a standard demand curve $D_{1}$ and a kinked one $D_{2}$ will give $D$ (Figure 2a). Having in mind the construction of the demand curve illustrated in Figure $2 b$ a fall in demand, due to a recession, will cause a shift to the left from $\mathrm{D}$ to $\mathrm{D}^{\prime}$. It is very likely that the kink of the demand curve will remain at the same price. This will be mainly due to the existence of customs which can also be a psychological basis for a hierarchical or threshold demand. In particular, people with similar incomes might, out of custom, expect an 'appropriate price' or the price that they are used to, for a given good (Earl, 1986). It is also quite possible that because of the large range of the vertical Marginal Revenue the firm will hold its price at $p_{0}$ while quantity will fall from $q$ to $q^{\prime}$ (the marginal revenue corresponding to the new demand curve is $\mathrm{MR}^{\prime}$ ). In the 


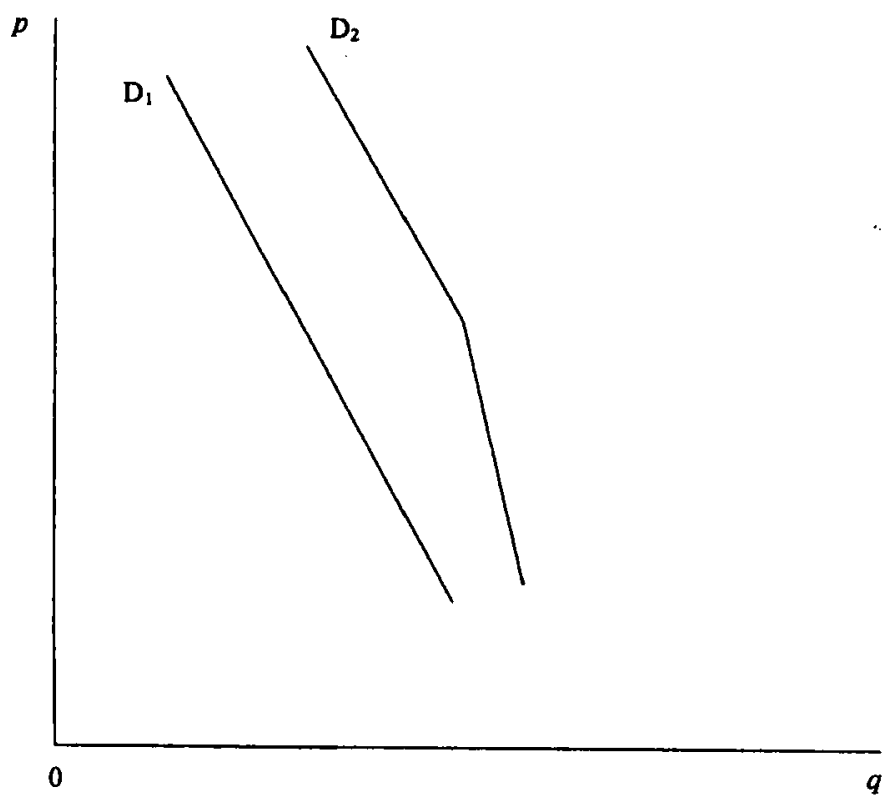

Figure 2a.

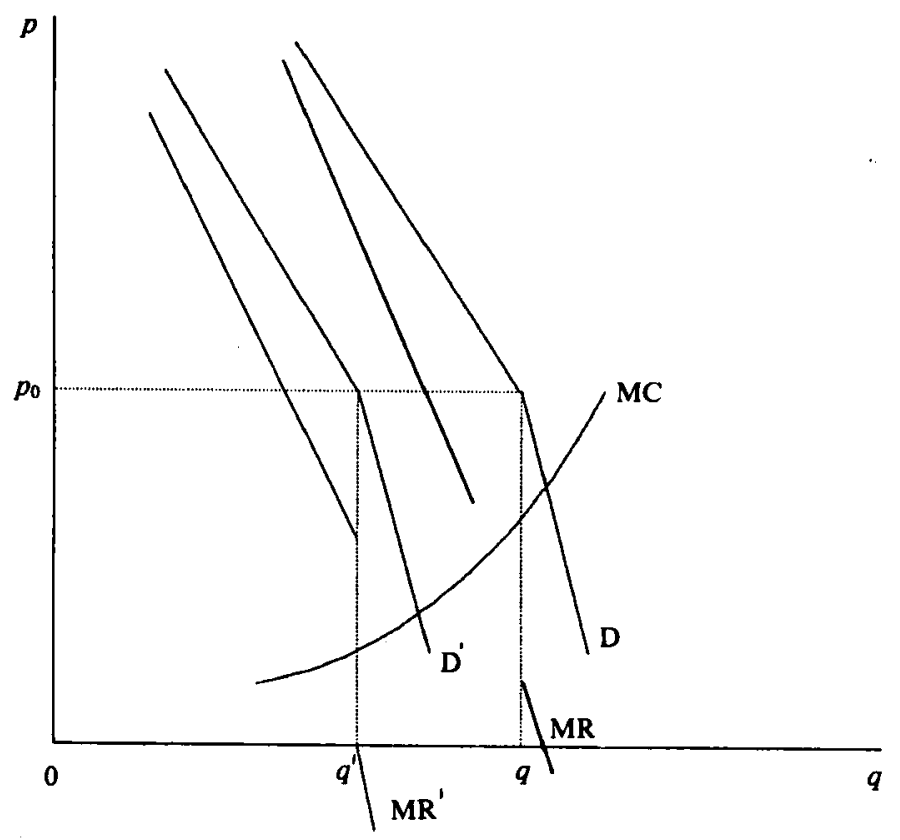

Figure 2b. 
case of fixed capacity there will be excess supply $q q^{\prime}$ which implies a nonmarket clearing situation.

One can compare this approach to other explanations of non-market clearing in the product side of the economy. For instance Okun's idea of 'shopping based on experience' and Stiglitz's 'information asymmetry' are similar (see Okun, 1981; Stiglitz, 1979). The important issue in our analysis is that the microeconomic foundations are coming from an alternative theory based on an interpretation of Keynes' views.

The basic idea here is that the Keynes' rejection of the utility maximizing or the expected utility model which ascribes perfectly optimal choices for economic agents, and his inclination towards the ideas that compose the alternative models that we described, can explain the price or quantity inertia that has been viewed as a mystery by many theorists in the Keynesian model.

\section{VII}

\section{CONCLUSION}

The starting point of this paper was the challenge to the idea held by many theorists of all persuasions that Keynes ascribed to the standard consumer behaviour theory. As was mentioned, there is evidence that Keynes had serious reservations about the standard theory. This objection is inconsistent with subsequent interpretation of the microfoundations of Keynes' macroeconomics by a number of theorists-including Neo-Keynesians-who wrongly assumed Keynes' implicit acceptance of the standard utility maximizing model. It is also inconsistent with attempts to derive Keynesian aggregate consumption functions based on standard consumer behaviour theory.

This opens the way to a number of questions about Keynes' microeconomic basis of his macroeconomics especially with respect to the theory of economic agents. Our interpretation suggested that he had in mind an alternative approach, signs of which can be found in his various writings. We attempted to combine these signs with models of consumer behaviour which have common points with Keynes' basic ideas. In particular, a hierarchically oriented theory which can be connected with the concept of threshold and habitual behaviour seems to be closer to his views. The next step was to see the implications of adopting such a theory for some classic macroeconomic problems of Keynesian thought which lack the necessary microfoundations. Thus problems such as sticky prices and Keynesian unemployment can be explained if one adopts this alternative consumer theory as a basis. Although there have been a number of other microeconomic explanations of these problems, the paper has attempted to tackle them from a relatively neglected viewpoint: consumer theory. 


\section{REFERENCES}

AKERLOF, G. and Yellen, J. (1985). Can small deviations from rationality make significant differences to economic equilibria?. American Economic Review, 75, pp. $708-720$.

ANDO, A. and Modigliani, F. (1963). The life cycle hypothesis of saving: aggregate implications and taste. American Economic Review, 53, 55-84.

ARrow K. (1974). Essays in the Theory of Risk Bearing. Amsterdam: North Holland.

Barro, R. J. and Grossman, H. (1971). A general disequilibrium model of unemployment. American Economic Review, 61, pp. 82-93.

Barro, R. J. and Grossman, H. (1976). Money, Employment and Inflation. Cambridge: Cambridge University Press.

Bateman, J. (1988). G. E. Moore and J. M. Keynes: a missing chapter in the history of the expected utility model. American Economic Review, 78, pp. 1098-1106.

BECKER, G. (1976). The Economic Approach to Human Behaviour. Chicago: The University of Chicago Press.

Bentham, J. (1823). An Introduction to the Principles of Morals and Legislation. Oxford: Clarendon Press.

BORCH, K. (1968). The Economics of Uncertainty. Princeton: Princeton University Press.

Carabell, A. (1988). On Keynes's Method. London: Macmillan.

ClOWER, R. W. (1965). The Keynesian counter-revolution: a theoretical appraisal. In Clower, 1969.

Clower, R. W. (1969). Monetary Theory. Penguin.

COATS, A. W. (1976). Economics and psychology: the death and resurrection of a research program. In S. Latsis (ed.), Method and Appraisal in Economics, Cambridge: University Press.

Davidson, P. (1983). Rational expectations. Journal of Post Keynesian Economics, 5, pp. $182-198$.

Devletoglou, N. and Demetriou, P. (1967). Choice and threshold: a further experiment in spatial duopoly. Economica, 34, pp. 351-371.

Dow, A. C. and Dow, S. C. (1985). Animal spirits and rationality. In T. Lawson and M. H. Pesaran (eds), Keynes' Economics: Methodological Issues. London: Croom Helm.

Dow, S. C. (1985). Macroeconomic Thought: A Methodoloaical Approach. London: Basil Blackwell.

Dow, S. C. (1989). Keynes's epistemology and economic methodology. University of Stirling, mimeo.

Drakopoulos, S. A. (1990a). Two levels of hedonistic influence on microeconomic theory. Scottish Journal of Political Economy, 37, pp. 360-378.

DraKopoulos, S. A. (1990b). The implicit psychology of the theory of rational consumer. Australian Economic Papers, 29, pp. 182-198.

Drakopoulos, S. A. (1991). Values and Economic Theory. Aldershot: Avebury.

Drakopoulos, S. A. (1992). Psychological thresholds, demand and price rigidity. The Manchester School, 60, pp. 152-168.

DUESENBERRY, J. (1949). Income, Saving and the Theory of Consumer Behaviour. Harvard: Harvard University Press.

EARL, P. (1983). The Economic Imagination. Brighton: Wheatsheaf.

EARL, P. (1986). Lifestyle Economics. Brighton: Wheatsheaf.

ENCARNACION, J. (1964). A note on lexicographical preferences. Econometrica, 32, pp. $718-755$.

FishBURN, P. (1974). Lexicographic orders, utilities and decision rules: a survey. Management Science, 20, pp. 1442-71.

Fisher, I. (1930). The Theory of Interest. New York: Macmillan.

Fitzgibions, A. (1988). Keynes's Vision. Oxford: Clarendon Press.

Frankena, W. (1963). Ethics. Englewood Cliffs: Prentice Hall.

Friedman, M. (1957). A Theory of Consumption Function. Princeton: National Bureau of Economic Research.

GARNER, A. (1983). Uncertainty in Keynes' general theory: a comment 2. History of Political Economy, 15, pp. 83-86. 
Georgescu-Roegen, N. (1966). Analytical Economics. Cambridge Mass: Harvard University Press.

GERRARD, B. (1991). Keynes's general theory: interpreting the interpretations. Economic Journal, 101, pp. 276-287.

GoRDON, R. (1990). What is new-Keynesian economics? Journal of Economic Literature, 28, pp. 1115-71.

HAHN, F. (1980). Unemployment from a theoretical viewpoint. Economica, 47, pp. $285-298$.

Hicks, J. (1946). Value and Capital. Oxford: Clarendon Press.

HICKS, J. and ALLEN, R. G. D. (1934). A reconsideration of the theory of value. Economica, 1, pp. 52-76.

HutCHISON, T. W. (1956). Bentham as an economist. Economic Journal, 66, pp. 208-306.

Jevons, W. S. (1871). The Theory of Political Economy. London: Macmillan.

JoHNSON, B. (1971). Household Behaviour. Penguin.

KEYNES, J. M. (1936). The General Theory of Employment, Interest and Money. London: Macmillan.

KeYNES, J. M. (1937). The General Theory of Employment. Quarterly Journal of Economics, 51, pp. 209-23.

KeYNES, J. M. (1972a). Essays in Biography, Collected Writings $X$. London: Macmillan.

Keynes, J. M. (1972b). The General Theory and After Part II: Defence and Development, Collected Writings XIV. London: Macmillan.

KeYNES, J. M. (1973). A Treatise on Probability, Collected Writings VIII. London: Macmillan.

KLEIN, L. (1949). The Keynesian Revolution. New York: Macmillan.

LAWson, T. (1985). Uncertainty and economic analysis. Economic Journal, 95, pp. 909-927.

LAWSON, T. (1987). The relative/absolute nature of knowledge and economic analysis. Economic Journal, 97, pp. 951-970.

LAwSON, T. (1988). Probability and uncertainty in economic analysis. Journal of Post Keynesian Economics, XI, pp. 66-81.

LEIJONHUFVUD, A. (1967). Keynes and the Keynesians: a suggested interpretation. In Clower, 1965.

LeIJONHUfVUd, A. (1968). On Keynesian Economics and the Economics of Keynes. Oxford: Oxford University Press.

LitTle, I. M. D. (1957). A Critique of Welfare Economics. Oxford: Clarendon Press.

LOASBY, B. (1978). Whatever happened to Marshall's theory of value? Scottish Journal of Political Economy, 25, pp. 1-28.

LOOMES, G. and SUGDEN, R. (1982). Regret theory: an alternative theory of rational choice under uncertainty. Economic Journal, 92, pp. 805-824.

LOOMES, G. and SUGDEN, R. (1983). A rationale for preference reversal. American Economic Review, 73, pp. 428-432.

Malinvaud, E. (1972). Lectures in Microeconomic Theory. Amsterdam: North Holland.

Malinvaud, E. (1977) The Theory of Unemployment Reconsidered. Oxford: Basil Blackwell.

Maslow, A. (1954). Motivation and Personality. New York: Harper and Row.

MCQUEEN, D. (1988). The hidden microeconomics of J. M. Keynes. In O. Hamunda and J. Smitth (eds) Keynes and Public Policy. Cheltenham: Edgar.

Meltzer, A. (1981). Keynes' general theory: a different perspective. Journal of Economic Literature, 19, pp. 481-517.

Modigliani, F. and BRUMBERG, R. (1955). Utility analysis and the consumption function. In K. Kurihara (ed.) Post Keynesian Economics. London: Allen and Unwin.

MoORE, G. E. (1966). Principia Ethica. Cambridge: Cambridge University Press.

MYERSON, R. (1981). Utilitarianism, egalitarianism and the timining effect in social choice problems. Econometrica, 49, pp. 883-897.

NeumanN, von J. and MoRGENSTERN, O. (1953). Theory of Games and Economic Behaviour. Princeton: Princeton University Press.

O'Donnell, R. M. (1989). Keynes: Philosophy, Economics and Politics. London: Macmillan. 
OKun, A. (1981). Prices and Quantities: A Macroeconomic Analysis. Washington: The Brookings Institution.

PAReto, V. (1971). Manual of Political Economy. Transl. by A. Schwier, London: Macmillan.

Patinkin, D. (1965). Money, Interest and Prices. New York: Harper and Row.

Patinkin, D. (1976). Keynes' Monetary Thought. Durham: Duke University Press.

PRELEC, D. (1982). Matching, maximizing and the hyperbolic reinforcement function. Psychological Review, 89, pp. 189-230.

RADNER, R. (1968). Competitive equilibrium under uncertainty. Econometrica, 36, pp. 31-58.

Samuelson, P. (1963). Foundations of Economic Analysis. Cambridge, Mass: Harvard University Press.

SavaGE, L. (1962). The Foundations of Statistical Inference. London: Methuen and Co.

SAWYER, J. (1989), Macroeconomic Theory. London: Harvester and Wheatsheaf.

SHACKLE, G. L. S. (1974). Keynesian Kaleidics. Edinburgh: University Press.

SkIdELSKY, R. (1983). John Maynard Keynes, Hopes Betrayed 1883-1920, 1. London: Macmillan.

SPEIGHT, A. (1990). Consumption, Rational Expectations and Liquidity. Hemel Hempstead: Wheatsheaf.

Stevenson, A. et al. (1988). Macroeconomic Theory and Stabilization Policy. Oxford: Philip Allan.

StIGLitz, J. (1979). Equilibrium in product markets with imperfect information. American Economic Review. Papers and Proceedings, 69, pp. 338-345.

SToнs, M. (1980). Uncertainty in Keynes' general theory. History of Political Economy, 12, pp. 372-82.

Streinbruner, J. (1974). The Cybernetic Theory of Decision. Princeton: Princeton University Press.

ToBIN, J. (1958). Liquidity preference and behavior towards risks. The Review of Economic Studies, 25, pp. 65-86.

VeBLEN, T. (1949). The Theory of the Leisure Class. London: Allen and Unwin.

Veblen, T. (1972). Professor Clark's economics. In E. K. Hunt and T. Schwartz (eds) A Critique of Economic Theory. Middlesex: Penguin.

Walras, L. (1965). Elements of Pure Economics. Transl. by W. Jaffe. London: Allen and Unwin.

WeintraUb, E. R. (1979). Microfoundations. Cambridge: Cambridge University Press.

WEISSMAN, D. L. (1984). Tobin and Keynes: a suggested interpretation. Journal of Post Keynesian Economics, 6.

Wong, S. (1978). The Foundations of Paul Samuelson's Revealed Preference Theory. London: Routledge and Kegan Paul. 